\begin{tabular}{|} 
Ambiente \& Água - An Interdisciplinary Journal of Applied Science \\
ISSN 1980-993X - doi:10.4136/1980-993X \\
www.ambi-agua.net \\
E-mail: ambi.agua@gmail.com
\end{tabular}

\title{
Quality of raw water in the Guandu Basin of Rio de Janeiro state during water crisis of 2020
}

\author{
ARTICLES doi:10.4136/ambi-agua.2703
}

Received: 01 Feb. 2021; Accepted: 24 May 2021

\author{
Adriana Sotero-Martins $^{1 *(\mathbb{D}}$; Aloysio da Silva Ferrão-Filho ${ }^{\complement}$; \\ José Augusto Albuquerque dos Santos ${ }^{2}{ }^{D}$; Priscila Gonçalves Moura ${ }^{3}{ }^{(D}$; \\ Natasha Berendonk Handam ${ }^{4}$; Nelson Peixoto Kotowski-Filho ${ }^{5}$; \\ Rodrigo Jardim Monteiro da Fonseca ${ }^{5}$; Elvira Carvajal ${ }^{6}$;
}

\footnotetext{
${ }^{1}$ Departamento de Saneamento e Saúde Ambiental. Escola Nacional de Saúde Pública Sérgio Arouca. Fundação Oswaldo Cruz (FIOCRUZ), Rua Leopoldo Bulhões, n 1480, CEP: 21041-210, Rio de Janeiro, RJ, Brazil.

${ }^{2}$ Instituto Oswaldo Cruz. Laboratório de Avaliação e Promoção da Saúde Ambiental. Fundação Oswaldo Cruz (FIOCRUZ), Avenida Brasil, n 4365, CEP: 21040-360, Rio de Janeiro, RJ, Brazil.

E-mail: aloysio@ioc.fiocruz.br, santosjaa@gmail.com

${ }^{3}$ Pós-Graduação em Saúde Pública e Meio Ambiente. Escola Nacional de Saúde Pública Sérgio Arouca.

Fundação Oswaldo Cruz (Fiocruz), Rua Leopoldo Bulhões, n 1480, CEP: 21041-210, Manguinhos,

Rio de Janeiro, RJ, Brazil. E-mail: priscila.moura.gema@gmail.com

${ }^{4}$ Programa de Doutorado em Saúde Pública e Meio Ambiente. Escola Nacional de Saúde Pública Sérgio Arouca

Fundação Oswaldo Cruz (FIOCRUZ), Rua Leopoldo Bulhões, n 1480, CEP: 21031-210, Rio de Janeiro, RJ, Brazil. E-mail: natashabhandam@gmail.com

${ }^{5}$ Instituto Oswaldo Cruz. Laboratório de Biologia Computacional e Sistemas. Fundação Oswaldo Cruz (FIOCRUZ), Avenida Brasil, n 4365, CEP 21040-900, Rio de Janeiro, RJ, Brazil.

E-mail: nelson.filho@ioc.fiocruz.br, rodrigo.jardim@ fiocruz.br

${ }^{6}$ Instituto de Biologia Roberto Alcantara Gomes. Departamento de Biologia Celular. Universidade do Estado do

Rio de Janeiro (UERJ), Rua São Francisco Xavier, n 524, CEP: 20550-900, Rio de Janeiro, RJ, Brazil.

E-mail: elvira.dbiocel@gmail.com

*Corresponding author. E-mail: adrianasotero@ensp.fiocruz.br
}

\begin{abstract}
At the beginning of 2020, about 9 million inhabitants of the Metropolitan Region of Rio de Janeiro, dependent on the Guandu Basin, experienced a water-supply crisis when their water tasted badly and gave off an odor. This work presents the results of analyses of the sanitary quality of raw water in this system at two different times during the water crisis, with respect to the presence of cyanobacteria found using metagenomic studies, and cyanotoxins, microcystin (MC) and saxitoxin (SXT) quantified by ELISA. Analyses of raw water quality parameters were carried out through the determination of total coliforms and Escherichia coli levels and some physical-chemical parameters. The raw water collected in both periods presented levels of Escherichia coli levels above the maximum allowed values (MAV) described in Resolution 357/2000 of the National Environmental Agency, as well as the levels of MC in a filter sample. The physical-chemical parameters analyzed and the SXT levels were in accordance with this resolution. The most abundant cyanobacterial genus in the critical period was Planktothricoides $s p$. Therefore, it is necessary to implement basic sanitation in cities upstream from the point of capture of raw water from this source, so that events similar to those that occurred in the 2020 water crisis do not recur.
\end{abstract}

Keywords: cyanotoxins, public health, raw water quality.

This is an Open Access article distributed under the terms of the Creative Commons Attribution License, which permits unrestricted use, distribution, and reproduction in any medium, provided the original work is properly cited. 


\section{Qualidade da água bruta da Bacia do Guandu do estado do Rio de Janeiro na crise hídrica de 2020}

\section{RESUMO}

No início do ano de 2020, cerca de 9 milhões de habitantes da Região Metropolitana do Rio de Janeiro dependente do Sistema Guandu, vivenciaram uma crise no abastecimento de água, recebendo água com gosto e odor. Este trabalho apresenta os resultados das análises sobre a qualidade sanitária da água bruta, captada por esse sistema, em dois momentos distintos durante a crise hídrica, quanto à presença de cianobactérias através de estudos de metagenômica, e de cianotoxinas na água bruta, através da quantificação de cianotoxinas, microcistina (MC) e saxitoxina (SXT) por ELISA. Foram realizadas análises de parâmetros de qualidade da água bruta, através da determinação dos níveis de coliformes totais e de Escherichia coli e de alguns parâmetros físico-químicos. A água bruta captada nos dois períodos apresentou níveis de Escherichia coli acima da faixa de valores máximo permitidos (VMP) descritos na Resolução 357/2000 do CONAMA, assim como o valor de MC em uma amostra de filtro. Os parâmetros físico-quimicos analisados e os níveis de SXT estavam em conformidade com essa resolução. O gênero de cianobactéria mais abundante no período crítico foi o Planktothricoides sp. Desta forma, é necessária a implementação do saneamento básico nas cidades a montante do ponto de captação de água bruta desse manancial, a fim de que eventos semelhantes aos ocorridos na crise hídrica 2020 não repitam.

Palavras-chave: cianotoxinas, qualidade sanitária da água bruta, saúde pública.

\section{INTRODUCTION}

The lack of sanitation in the cities upstream of the point of captation of water from the spring used by water treatment plants (WTS) means that the cities are consuming a type of indirect reuse water (Hespanhol, 2015; Moura, 2019). As described by Hespanhol (2015), this occurs when effluents are discharged into the environment (upstream), and are again used downstream, in their diluted form, in an unintentional and uncontrolled manner.

In this way, in the Guandu River Basin, sewage discharged into the waters of the Ipiranga, Queimados and Poços Rivers brings a load of nutrients to the water bodies, which combines with the high luminosity and low movement of the water in lagoons near the point of capture of raw water and favors the growth of microorganisms (INEA, 2012). As several species of cyanobacteria produce toxins, the release of treated or untreated effluents containing toxins into the receiving body may eventually affect the aquatic biota, causing changes in the food chain by inhibiting the development of other organisms (Lapolli et al., 2011; Ferrão-Filho and Kozlowsky-Suzuki, 2011), in addition to the production of taste and odor compounds (T\&O) such as geosmin and 2-methylisoborneol (2-MIB), causing water-supply crises (Bruchet, 2019). The raw water from Guandu, distributed to the municipalities of the Metropolitan Region of Rio de Janeiro (RMRJ), is treated at the Guandu Treatment Plant and supplies about 9 million inhabitants, who experienced a water supply crisis in January 2020, when their water developed a disagreeable taste and odor (Sotero-Martins et al., 2017).

In the raw water collected for supply, treatment processes are employed to avoid the presence of cyanobacteria in the treated water, thereby reducing unhealthy cyanotoxin concentrations. The massive growth of cyanobacteria tends to cause unpleasant taste and odor in the water, as well as an imbalance in the local phytoplankton community, since they tend to be dominant over other species. However, the biggest problem associated with the presence of cyanobacteria concerns the production of cyanotoxins (Lapolli et al., 2011). Thus, the risk of returning to conditions conducive to the proliferation of cyanobacteria and favoring the 
production of cyanotoxins in water sources must be constantly monitored in order to prevent the population supplied from being exposed to adverse conditions (Brasil, 2016). Most of the cyanotoxins identified appear to be more dangerous to land mammals than to aquatic biota (Sivonen and Jones, 1999). Therefore, the uptake of raw water contaminated with cyanobacteria potentially producing cyanotoxins constitutes a health risk, and these molecules can lead to chronic diseases and even death. In this regard, it is necessary to constantly monitor the reservoirs to avoid episodes such as those that occurred in Itaparica in 1988, which led to the death of 88 people and the intoxication of 2000 others (Teixeira et al., 1993), as well as in Caruaru, when in 1996 hemodialysis devices treated with contaminated water caused 76 deaths (Carmichael et al., 2001). It is also worth remembering the cases that occurred in Pennsylvania in 1975, when 5000 people had gastrointestinal infection due to contaminated water (Falconer, 1994).

The aim of this work was to verify the sanitary quality of the raw water of the Guandu Basin, destined for treatment for human consumption in the Metropolitan Region of the state of Rio de Janeiro, and in particular the presence of cyanobacteria associated with the production of substances that cause odor and smell, and cyanotoxins, during two periods of the water crisis of 2020 .

\section{MATERIALS AND METHODS}

The raw water samples were collected at the intake points of water treatment plants of Guandu Water Treatment Station (WTS) (Latitude -22,80922 and Longitude -43,62700), representing the "water crisis" period. Within this period, samples were collected on 01/13/2020, during the first survey conducted by the Public Prosecutor's Office of the State of Rio de Janeiro, Environmental Specialized Performance Group (MP/GAEMA), who authorized the collections, after complaints about water quality by the population regarding organoleptic standards. More samples were collected on 09/03/2020, during the 2nd inspection at the MP/GAEMA, evaluating the measures taken by the company to minimize and/or eliminate the problem. The collections were performed according to procedures described in the "Manual Cyanobacteria / Cyanotoxins: procedures for collection, preservation and analysis", of the Ministry of Health (Brasil, 2015). The project was registered at SisGen (AB91094 register).

The physical-chemical and coliform analysis were conducted as described by Handam et al. (2020) and according to Standard Methods for the Examination of Water and Wastewater (APHA et al., 2012). In the coliform analysis, the levels of total coliforms (TC) and Escherichia coli (EC) were evaluated, as described by Sotero-Martins et al. (2017), through the filter membrane methodology, with chromogenic substrate. The following parameters were considered: Total hardness $\left(\mathrm{mg} / \mathrm{l} \mathrm{CaCO}_{3}\right) ; \mathrm{pH}$; Conductivity $(\mu \mathrm{S} / \mathrm{cm})$; Total dissolved solids (mg/l); Chlorides (mg/l); Total alkalinity (mg/l $\left.\mathrm{CaCO}_{3}\right)$; Turbidity (NTU); Ammonia (mg/l); Total residual chlorine $\left(\mathrm{mg} / \mathrm{L} \mathrm{Cl}^{-}\right)$; and Sulfate $\left(\mathrm{mg} / \mathrm{l} \mathrm{SO}{ }_{4}{ }^{=}\right)$.

The presence of cyanotoxins, microcystin (MC) and saxitoxin (STX), was verified in samples of both periods, with the $1^{\text {st }}$ inspection maintained frozen and the 2 nd inspection maintained in two forms of preservation: at $4^{\circ} \mathrm{C}$ for $24 \mathrm{~h}$ after collection and frozen in freezer $20^{\circ} \mathrm{C}$. All samples were thawed and submitted to ultrasound for 15 minutes for rupture of the cells. The $2^{\text {nd }}$ inspection sample was concentrated by filtration on a $47 \mathrm{~mm}$ diameter fiberglass GF/C membrane and porosity of $1.2 \mu \mathrm{m}$ (Whatman GF/C, Millipore), retaining the particulate material in suspension (Andersen, 2005). A volume of $250 \mathrm{~mL}$ of the samples was submitted to $\mathrm{MC}$ extraction with $0.1 \%$ trifluoroacetic acid (TFA) in methanol, macerating the fiberglass membranes and then centrifuging $1350 \mathrm{xg}$ with supernatant collection (Sanches et al., 2007). The same procedure was performed for the extraction of SXT, with the $0.1 \mathrm{~N}$ glacial acetic acid solution for the maceration of the filters (Aragão et al., 2016). The sample for MC contained in the filters was evaporated with air jet until complete dryness, being later resuspended in $1 \mathrm{ml}$ 
of ultra-pure water, while the sample for SXT was frozen and lyophilized, being later resuspended in $1 \mathrm{ml}$ of ultra-pure water. The samples were analyzed in Beacon's (Analytical Systems) Enzyme-Linked Immuno-sorbance Assay (ELISA) using a microplate reader (Thermo Plate Reader), and the results expressed in $\mu \mathrm{g} / \mathrm{l}$.

The sample of the first metagenomic survey was in limited volume conditions, being considered rare $(700 \mathrm{ml})$. Therefore, it underwent ultracentrifugation for 2 hours $(100,000 \mathrm{x} \mathrm{g})$ to $4^{\circ} \mathrm{C}$. DNA was extracted using the DNEasy kit of Quiagen, following information from the manufacturer. In the 2 nd inspection, the volume of 10 liters was filtered in nitrocellulose membranes of $0.8 \mu \mathrm{m} ; 0.45 \mu \mathrm{m}$ and $0.22 \mu \mathrm{m}$ of porosity. The extraction of DNA was realized in the kit "PowerWater ${ }^{\circledR}$ SterivexTM DNA Isolation Kit Sample" (MO bio laboratories, Inc). The process of metagenomic analysis was realized as described in Moura et al. (2020a), and the construction of the libraries was done with the Nextera DNA FLEX 2x150 bp paired-end kit from Illumina, following the manufacturer's instructions. The DNA was quantified at Qubit $^{\mathrm{TM}}$ and the sample sizes were analyzed with DNA Sensitivity bioanalyzer before the sequencing. The sequencing was performed at the SENAI CETIQT Innovation Institute for Biosynthetic and Fibers sequencing facility using Illumina's NextSeq 550 (Illumina, INC, USA). The sequenced data were analyzed on the Stingray@ Galaxy platform. The quality of the sequences was evaluated by the FastQC tool, Version 0.67 . The similarity search was completed using Diamond software, Version 0.9.29 with the standard parameters, except for e-value 1e05, against the National Center of Biotechnology Information (NCBI, 2019) reference cured database RefSeq Protein release 2019. The results of the analyses were viewed in Megan, Version 6 and KronaTools, Version 1.1.0 programs. After analysis in Diamond, the rarefaction curves and alpha diversity calculation were done by the Shannon-Weaver method, by the Megan program (Version 6); data cleaning was done by the Trimmomatic software (Version $0.32)$.

\section{RESULTS AND DISCUSSION}

\subsection{Colorimetric and Physical-Chemical Indicators}

The EC levels at the intake points of water treatment plants of Guandu in the second survey were not in conformity with the most-probable-number (MPN) described in the National Environmental Council (CONAMA) Resolution no. 357/2005 (CONAMA, 2005). It averaged $94 \times 10^{3} \mathrm{NMP} / 100 \mathrm{ml}$; that is 94 times above the MPN described in the Brazilian legislation. Therefore, it was much above the necessary quality for capture for treatment, indicating high contamination by sewage in the waters of this spring. Although the legislation does not treat the levels of total coliforms, the level of this parameter was on average $1393 \times 10^{3} \mathrm{MPN} / \mathrm{ml}$, demonstrating that the waters of this spring usually have high rates of enteric microorganisms, being improper for WTS capture. Comparing the results obtained in this study with those published by the State Environmental Institute (INEA), the levels of thermotolerant coliforms in the first survey were $9.0 \times 10^{2} \mathrm{MPN} / 100 \mathrm{ml}$; therefore the raw water was suitable for capture. However, five days before this date, the results for this parameter were not in conformity, being $7.9 \times 10^{3} \mathrm{MPN} / 100 \mathrm{ml}$, on 01/09/2020.

According to the CONAMA Resolution $n^{\circ} 357 / 2005$ for Class 2 water from springs, which is the class of raw water collected by WTS, the levels of thermotolerant coliforms should not exceed 1,000 MPN/100 ml. in $80 \%$ or more of at least six(6) samples collected during the period of one year, with bimonthly frequency. Although this study was not conducted in this situation, this value was used as a reference for comparing results. The same resolution establishes that the levels of $E$. coli may be determined in substitution of the thermotolerant coliform parameter (CONAMA, 2005). According to Santos et al. (2018) samples with high levels of thermotolerant coliforms, above the permitted level, may indicate contamination due to animal 
feces that border the river banks, as well as sewage discharges along the rivers, which are devoid of sanitation, as a sewage collection network. It is important to point out that the collections made during the first survey were made close to rainy days and, according to Santos et al. (2018), this may cause the carrying of a large amount of sediments and effluents located upstream to downstream of the river. The levels of thermotolerant coliforms also indicate that in the region there may be a recent discharge of sewage, which increases the possibility of having other pathogenic organisms in the water collected, which may also cause other diseases by water transport (Brasil, 2017; Moragas, 2005).

As the classification of the raw water collected from Guandu is framed in Class 2, all analyzed physical-chemical parameters were within the maximum allowable value (MAV) described in Resolution CONAMA n ${ }^{\circ}$ 357/2005 (CONAMA, 2005), in both surveys. Despite the parameters of total hardness and alkalinity, no MAV are described in Resolution no.357/2005; they are described in the Brazilian Potable Water Legislation $n^{\circ} 5 / 2007$ of Ministry of Health (MH), and wereused in this work, and also by INEA, and in both survey periods the raw water was proper (Table 1).

Table 1. Physical-chemical analysis of raw water samples from Guandu's WTS in the two survey periods - 13/01/2020 (1st survey) and 09/03/2020 (2nd survey). And the maximum allowable value (MAV) for water capture for supply of CONAMA Resolution no. 357/2005 - Classes 1 and 2, and the MH’s Potable Water Legislation nº of 2017.

\begin{tabular}{|c|c|c|c|c|c|}
\hline \multirow[b]{2}{*}{ Parameters } & \multirow[b]{2}{*}{ 1st survey } & \multirow[b]{2}{*}{ 2nd survey } & \multicolumn{2}{|c|}{$\begin{array}{c}\text { Resolution } \mathrm{n}^{\mathrm{o}} \\
\text { 357/2005 (MAV) }\end{array}$} & \multirow{2}{*}{$\begin{array}{l}\text { MH's Legislation } \\
n^{\circ} 5 / 2017 \text { (PMV) }\end{array}$} \\
\hline & & & Class 1 & Class 2 & \\
\hline $\begin{array}{l}\text { Total hardness } \\
\left(\mathrm{mg} / \mathrm{CaCO}_{3}\right)\end{array}$ & 20,00 & 10,91 & NS & NS & 500 \\
\hline $\mathrm{pH}$ & 6,2 & 6,33 & $6-9$ & NS & $6-9,5$ \\
\hline $\begin{array}{l}\text { Conductivity } \\
(\mu \mathrm{S} / \mathrm{cm})\end{array}$ & 71,5 & 76,00 & NS & NS & NS \\
\hline $\begin{array}{l}\text { Total dissolved solids } \\
\text { (mg/l TDS) }\end{array}$ & 38,6 & 37,80 & 500 & NS & 1000 \\
\hline $\begin{array}{l}\text { Chlorides } \\
\left(\mathrm{mg} / \mathrm{l} \mathrm{Cl}{ }^{-}\right)\end{array}$ & 4,40 & 4,40 & 250 & NS & 250 \\
\hline $\begin{array}{l}\text { Total alkalinity } \\
\left(\mathrm{mg} / \mathrm{l} \mathrm{CaCO}_{3}\right)\end{array}$ & 40 & 32,50 & NS & NS & 250 \\
\hline Turbidity (uT) & 4,18 & 46,10 & 40 & 100 & 5 \\
\hline
\end{tabular}

Legend: NS = No standard parameter values defined in the laws. Resolution CONAMA $\mathrm{n}^{\circ} 357 / 2005$ (CONAMA, 2005) - class 1. Resolution CONAMA $\mathrm{n}^{\circ} 357 / 2005$ (CONAMA, 2005) - class 2. Potable Water Legislation of Ministry of Health - $n^{\circ} 5 / 2027$ (Brasil, 2017).

\subsection{Microcystin and Saxitoxin Analysis}

The results of the ELISA analysis for STX show that the raw water was in satisfactory condition. However, for $\mathrm{MC}$, in the sample of the particulate material retained in the GF/C membranes, the result was not in conformity with the MPV described in the Potable Water Legislation of Ministry of Health n.05/2017 - Annex XX. This result is due to the higher concentration of the sample in the GF/C membranes, which increases the detection power of the test (Ferrão-Filho et al., 2009). Although the analysis of cyanotoxins in water samples for human supply is a requirement of the Ministry of Health, the ordinance of potability does not establish the method of extraction and analysis to be used. The quantification of toxins is commonly performed by ELISA or HPLC; however, the efficiency depends on the processing and extraction method used. According to Silva-Stenico et al. (2009), the extraction method with ultrasound in water is a simple, fast and inexpensive method that has proven to be more 
efficient. Therefore, when comparing the MC levels in the samples of the two periods, processed by methodology usually used by INEA and water treatment companies, the values were very close to MPV (Table 2).

Table 2. Microcystin (MC) and saxitoxin (STX) values in Guandu samples.

\begin{tabular}{lcccc}
\hline Samples & Date & MC $(\boldsymbol{\mu g} / \mathbf{l})$ & STX $(\boldsymbol{\mu g} / \mathbf{l})$ & Note \\
\hline Raw Water (point 1) & \multicolumn{3}{c}{ 1st survey } \\
\hline Raw Water - Frozen & $09 / 03 / 2020$ & $<0.10$ & $<0.02$ & $\begin{array}{c}\text { Sample of frozen raw water } \\
\text { Sample of raw water kept in } \\
\text { refrigerator }\end{array}$ \\
Raw water - Cooled (point 1) & $09 / 03 / 2020$ & 0,16 & $<0,02$ & $\begin{array}{c}\text { Sample of frozen raw water } \\
\text { Raw Water-Filter (point 1) }\end{array}$ \\
Rand survey & $09 / 03 / 2020$ & 1.19 & 0.80 & $\begin{array}{c}\text { Sample filtered and frozen } \\
\text { raw }\end{array}$ \\
\hline Limit detection & & $\mathbf{0 . 1}$ & $\mathbf{0 . 0 2}$ & \\
\hline $\begin{array}{l}\text { Maximum Allowable } \\
\text { Value (*) }\end{array}$ & & $\mathbf{1 . 0}$ & $\mathbf{3 . 0}$ & \\
\hline
\end{tabular}

(*) Potable Water Legislation 05/2017 - Anexo XX.

When comparing the results of this work with the data described in the INEA reports of day 01/13/2020, processed similarly only with freezing of the samples, the results obtained by this institute for the levels of cyanotoxins evaluated were similar to those analyzed in the same periods that the collections of this work were made, being $0.119 \mu \mathrm{g} / \mathrm{L}$ of $\mathrm{MC}$ and $<0.02 \mu \mathrm{g} / \mathrm{L}$ of SXT.

The sample collected in the first survey with the phytoplankton concentration network, after filtration in membranes $0.8 \mu \mathrm{m} ; 0.45 \mu \mathrm{m}$ and $0.22 \mu \mathrm{m}$ of porosity, showed blue color, as well as remained in the filtrate. This color characterizes the production of the phycocyanin pigment in high concentrations by the cyanobacteria during flowering (Utsumi et al., 2015). According to the CEDAE report, the concentration of cyanobacteria cells that day was 16,768 cells/mL (CEDAE, 2020), above the MPV for raw water capture (Brasil, 2017). As the Potable Water Legislation No.5/2017 establishes that the analysis of cyanotoxins is only mandatory when the cell density exceeds 20,000 cells/ml, CEDAE did not make the analysis of raw water toxins, so it was not possible to compare them with the values found in this study.

\subsection{Main Genera Indicated by the Ministry of Health as producers of cyanotoxins found in the genetic sequences of samples}

In the two surveys, genomic sequences corresponding to the genera of cyanobacteria related to the production of cyanotoxins were identified, indicated in reference of the Ministry of Health (Brasil, 2015). In the raw water sample at the time of the first survey (01/13/2020), $5 \%$ of sequences for cyanobacteria were found, representing 11 genera out of a total of 12 genera listed in this reference of the $\mathrm{MH}$ of Brazil, related to cyanobacteria potentially producing neurotoxins. Fourteen genera were also found, out of a total of 22 genera listed in this reference, related to potentially hepatotoxic producing cyanobacteria. In the sample collected in the 2nd survey (03/09/2020), the percentage of genetic sequences present for cyanobacteria was reduced; i.e., from the total of sequences within the domain for bacteria, only $1 \%$ of the genetic sequences corresponded to cyanobacteria, represented by only 2 genera related to the genetic potential for production of neurotoxins and 3 genera related to production of hepatotoxins (Table 3). 
Table 3. Genera of cyanobacteria present (+) or absent (-) in the genetic sequences of the samples, based on a Ministry of Health reference (Brasil, 2015), in two collection periods, the 1st survey and the 2nd survey.

\begin{tabular}{|c|c|c|c|c|c|}
\hline \multicolumn{4}{|c|}{ Neurotoxins } & \multicolumn{2}{|c|}{ Hepatotoxins } \\
\hline & 1st survey & 2nd survey & & 1st survey & 2nd survey \\
\hline Aphanizomenon & + & - & Anabaena & + & - \\
\hline Arthrospira & + & - & Anabaenopsis & - & - \\
\hline Cylindrospermum & + & - & Aphanocapsa & - & - \\
\hline Oscillatoria & + & + & Arthrospira & + & - \\
\hline Phormidium & + & - & Fischerella & + & - \\
\hline Planktothrix & + & - & Gloeotrichia & - & - \\
\hline Anabaena & + & - & Hapalosiphon & + & - \\
\hline Raphidiopsis & + & - & Microcystis & + & - \\
\hline Cylindrospermopsis & + & - & Nostoc & + & + \\
\hline Planktolyngbya & - & - & Oscillatoria & + & + \\
\hline Hydrocoleum & + & - & Phormidium & + & - \\
\hline \multirow[t]{11}{*}{ Lyngbya } & - & + & Planktothrix & + & - \\
\hline & & & Plectonema & - & - \\
\hline & & & Radiocystis & - & - \\
\hline & & & Synechocystis & + & - \\
\hline & & & Woronichinia & - & - \\
\hline & & & Cylindrospermopsis & + & - \\
\hline & & & Aphanizomenon & + & - \\
\hline & & & Lyngbya & - & + \\
\hline & & & Raphidiopsis & + & - \\
\hline & & & Umezakia & - & - \\
\hline & & & Nodularia & + & - \\
\hline
\end{tabular}

Although the genus Planktothricoides is not listed in the main MH reference of Brazil (Brasil, 2015), this was the most abundant genus in the 1st survey sample (Moura et al., 2020b). However, at the time of the 2nd survey, this genus was not found among the sequences analyzed by metagenomics. According to Komárek (2003), the bacteria of the genus Planktothricoides were classified as Planktothrix, because they are morphologically very similar. Although they are genetically distinct, both genera found in raw water samples during the 1st survey have a genomic repertoire capable of producing terpenic odiferous substances that confer taste and odor in water, being also producers of cyanotoxins of importance for public health, such as microcystin (hepatotoxin), saxitoxins and $\beta-N$-methylamino-L-alanine - BMAA (neurotoxins), among others (Te et al., 2017; Cox et al., 2005). Among the T\&O compounds identified, geosmin and 2-methylisoborneol (2-MIB), responsible for musty or earthy odor, are considered to be the most commonly involved in drinking water quality alteration events (Bruchet, 2019; Lee et al., 2017; Watson et al., 2016). Other volatile organic compounds produced by cyanobacteria, such as sulfur compounds, carotenoid derivatives, fatty acid derivatives, amines, and terpenoids, are also associated with unpleasant taste and odor problems in water (Bruchet, 2019). These compounds, although they do not pose a risk to human health, cause insecurity and lack of confidence in the population, leading to complaints about water quality. In addition, the toxins produced can be released together in the collection of raw water collected to be treated at the Water Treatment Station (WTP), as happened for these products that changed the water taste and odor parameters (Ferreira Filho and Alves, 2006) distributed to the metropolitan population. Events also with limited sampling placed California and Mississippi (Izaguirre, 1992; Martin et al., 1991, respectively) on the CyanoGM Explorer scenario map involving T\&O compounds produced by cyanobacteria (https://cyanogmexp.ncku.edu.tw). 


\section{CONCLUSIONS}

The level of Escherichia coli, the main bioindicator parameter of the recent presence of sewage in raw water, was above MAC in both periods, even for Class 2 raw water, according to Resolution no.357/2005. This result indicates how much the Guandu River Basin is impacted by the lack of sanitation in the cities upstream of the water catchment point used by the Guandu WTP. In other words, the basin is impacted by the pollution via sanitary sewage and also by the receipt of industrial effluents; therefore, the water security of the water supply goes through the protection of the river basin. Consequently, the metropolitan region of Rio de Janeiro is consuming an unplanned type of indirect reuse water (Moura et al., 2020b). Therefore, this unintentional and uncontrolled reuse needs to be modified to the controlled status, through the urgent and necessary basic sanitation in the cities upstream of the water catchment, in order to not experience water crisis events.

As for cyanotoxin dosage, the processing, extraction and analysis method needs to be adjusted in order to increase the detection power of these compounds. This is necessary for an adequate evaluation of the real risk related to the presence of this type of contaminant in the raw water captured by the water treatment plant. Because they are very diluted in the raw water sample, often the toxins can be below the detection limit of the method used, so that the most efficient monitoring involves the use of a method that increases the sensitivity of the analysis to ensure better assessment of the risk to human populations.

Most of the genera of bacteria found in the 2nd survey were lake and spring plankton used by the WTP. Therefore the decrease in the diversity of cyanobacteria genera with genetic potential for cyanotoxin production, demonstrated that the control and mitigation palliative measures to reduce taste and odor in drinking water worked. However, a warning was given that similar events may tend to become more frequent and critical in the future, especially in case of water shortage. Thus, definitive measures and management actions such as sanitation of the drainage basins in the water resources need to be adopted urgently in order to ensure the water security of the Paraíba do Sul River Basin, so as not to compromise the quality of the water supply for users dependent on this river basin.

\section{ACKNOWLEDGEMENTS}

This study was financed in part by the Coordination for the Improvement of Higher Education Personnel (Coordenação de Aperfeiçoamento de Pessoal de Nível Superior CAPES) - Finance Code 001. And by the Vice-Presidency of Environment, Attention and Health Promotion (VPAAPS) of Fiocruz for the financing, and the Post-Graduation Program for the inclusion of the post-doc, and payment of the scholarship of doctoral students by the Fundação Carlos Chagas Filho de Amparo à Pesquisa do Estado do Rio de Janeiro (FAPERJ), process number E-26/200.393/2020. And support from the Public Prosecution Service of the State of Rio de Janeiro, through the Environmental Specialized Performance Group (GAEMA) for the opportunity in the development of this work.

\section{REFERENCES}

ANDERSEN, R. A. Algal Culturing Techniques. Amsterdam: Elsevier, 2005. 578p.

\section{APHA; AWWA; WEF. Standard Methods for the examination of water and wastewater.} 22nd ed. Washington, 2012. 1496 p. 
ARAGÃO, M. C.; ABREU, A. Z.; CAPELO NETO, J. Estabilidade de Saxitoxinas GTX 2/3, dc-GTX 2/3 e C1/2 em água de abastecimento e impactos na validação de método analítico. Revista DAE, v. 203, p. 80-95, 2016.

BRASIL. Ministério da Saúde. Cianobactérias/cianotoxinas: procedimentos de coleta, preservação e análise. Brasília, 2015. 106 p. Available at: www.saude.gov.br/svs Access: 2020 Jan. 20.

BRASIL. Ministério da Saúde. Orientações técnicas para o monitoramento de cianobactérias/cianotoxinas nos mananciais de abastecimento de água para consumo humano. Brasília, 2016. 22 p. Available at: https://bvsms.saude.gov.br/bvs/publicacoes/orientacoes_tecnicas_cianobacterias_cianot oxinas_agua.pdf. Access: 2020 Jan. 20.

BRASIL. Ministério da Saúde. Portaria n. 05, de 28 de setembro de 2017. Consolidação das normas sobre as ações e os serviços de saúde do Sistema Único de Saúde. Diário Oficial [da] União: seção 1, Brasília, DF, n. 190, supl. p. 516-531, 03 de out. de 2017.

BRUCHET, A. Chemical analytical techniques for taste and odour compounds. In: LIN, T.-F.; WATSON, S.; DIETRICH, A. M.; SUFFET, I. H. (Eds.). Taste and Odour in Source and Drinking Water: Causes, Controls, and Consequences. IWA Publishing, 2019. https://dx.doi.org/10.2166/9781780406664_0113

CARMICHAEL, W. W. et al. Human fatalities from cyanobacteria: Chemical and biological evidence for cyanotoxins. Environmental Health Perspectives, v. 109, p. 663-668, 2001. https://dx.doi.org/10.1289/ehp.01109663

CEDAE. Qualidades da água: relatórios Guandu - Ano 2020. Available at: https://www.cedae.com.br/relatoriosguandu. Access: 2020 Jan. 20.

CONAMA (Brasil). Resolução no 357 de 17 de março de 2005. Dispõe sobre a classificação dos corpos de água e diretrizes ambientais para o seu enquadramento, bem como estabelece as condições e padrões de lançamento de efluentes, e dá outras providências. Diário Oficial [da] União: seção 1, Brasília, DF, n. 053, p. 58-63, 18 mar. 2005.

COX, P. A. et al. Diverse taxa of cyanobacteria produce $\beta-\mathrm{N}$-methylamino-L-alanine, a neurotoxic amino acid. Proceedings of the National Academy of Sciences of the United States of America, v. 102, n. 14, p. 5074-5078, 2005. https://doi.org/10.1073/pnas.0501526102

FALCONER, I. Toxicity of the Blue-Green Alga (Cyanobacterium) Microcystis aeruginosa in drinking water to growing pigs, as an animal model for human injury and risk assessment. Environmental Toxicology and Water Quality: An International Journal, v. 9, p. 131-139, 1994. https://doi.org/10.1002/tox.2530090209

FERRÃO-FILHO, A. S.; KOZLOWSKY-SUZULI, B. Cyanotoxins: bioaccumulation and effects on aquatic animals. Marine Drugs, v. 9, p. 2729-2772, 2011. https://dx.doi.org/10.1007/s11356-019-04851-6

FERRÃO-FILHO, A. S.; SOARES, M. C. S.; MAGALHÃES, V. F.; AZEVEDO, S. M. F. O. Biomonitoring of cyanotoxins in two tropical reservoirs by cladoceran toxicity bioassays. Ecotoxicology and Environmental Safety, v. 72, p. 479-489, 2009. https://doi.org/10.1016/j.ecoenv.2008.02.002 
FERREIRA FILHO, S. S.; ALVES, R. Técnicas de avaliação de gosto e odor em águas de abastecimento: método análitico, análise sensorial e percepção dos consumidores.

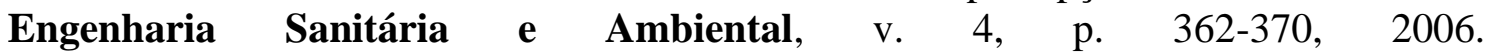
https://doi.org/10.1590/S1413-41522006000400009

HANDAM, N.; SANTOS, J.; MORAES NETO, A.; ALENCAR, M., IGNACIO, C., SOTEROMARTINS, A. Drinking water quality in Brazilian urban slums. Revista Ambiente \& Água, n. 15, v. 3, p. 1-11, 2020. https://dx.doi.org/10.4136/ambi-agua.2532

HESPANHOL, I. Reúso potável direto e o desafio dos poluentes emergentes. Revista USP, n. 106, p. 79-94, 2015. https://doi.org/10.11606/issn.2316-9036.v0i106p79-94

INEA. Bacia Hidrográfica dos Rios Guandu, da Guarda e Guandu-Mirim Experiências para a gestão dos recursos hídricos. São Paulo, 2012, 340 p.

IZAGUIRRE, G. A Copper-Tolerant Formidium Species from Lake Mathews, California, That Produces 2-Methylisoborneol and Geosmin. Water Science and Technology, v. 25, n. 2, p. 217-223, 1992. https://doi.org/10.2166/wst.1992.0055

KOMÁREK, J. Planktic oscillatorialean cyanoprokaryotes (short review according to combined phenotype and molecular aspects). In: NASELLI-FLORES, L.; PADISÁK, J.; DOKULIL, M. T. (eds.). Phytoplankton and Equilibrium Concept: The Ecology of Steady-State Assemblages. Dordrecht: Springer, 2003. https://doi.org/10.1007/978-94017-2666-5_30

LAPOLlI, F. R.; CORAL, L. A.; RECIO, M. Á. L. Cianobactérias em mananciais de abastecimento problemática e métodos de remoção. Revista DAE, n. 185, 2011. https://dx.doi.org/10.4322/dae.2014.066

LEE, J.; RAI, P. K.; JEON, Y. J.; KIM, K. H.; KWON, E. E. The role of algae and cyanobacteria in the production and release of odorants in water. Environmental Pollution, v. 227, p. 252-262, 2017. https://doi.org/10.1016/j.envpol.2017.04.058

MARTIN, J. F.; IZAGUIRRE, G.; WATERSTRAT, P. A planktonic Oscillatoria species from Mississippi catfish ponds that produces the off-flavor compound 2-methylisoborneol. Water Research, v. 25, n. 12, p. 1447-1451, 1991. https://doi.org/10.1016/00431354(91)90173-N

MORAGAS, W. M. Análise dos sistemas ambientais do alto Rio Claro - sudoeste de Goiás: contribuição ao planejamento e gestão. 2005. Tese (Doutorado em Geografia) Instituto de Geociências e Ciências Exatas, Universidade Estadual Paulista, Rio Claro, 2005.

MOURA, P. G. Metagenômica da água de reúso: esgoto e água potável. 2019. Tese (Doutorado em Saúde Pública e Meio ambiente) - Escola Nacional de Saúde Pública Sérgio Arouca, Fundação Oswaldo Cruz, Rio de Janeiro, 2019.

MOURA, P. G.; KOTOWSKI FILHO, N. P.; CARVAJAL, E.; HANDAM, N. B.; JARDIM, R.; SOTERO-MARTINS, A. Rio de Janeiro water crisis: a metagenomic approach. Scielo PrePrints, 21 maio 2020a. https://dx.doi.org/10.1590/ScieloPreprints.529

MOURA, P. G; ARANHA, F. N.; BEREBDONK, N. H.; MARTINS, L. E.; SALLES, M. J.; CARVAJAL, E. et al. Água de reúso: uma alternativa sustentável para o Brasil. Engenharia Sanitária e Ambiental, v. 25, n. 6, p. 791-808, 2020b. https://doi.org/10.1590/S1413-4152202020180201 
NCBI. Taxonomy Browser: Bradyrhizobium. ncbi:txid374. Available at: https://www.ncbi.nlm.nih.gov/Taxonomy/Browser/wwwtax.cgi?lvl=0\&amp;id=374 Access: 2019 Nov. 20.

SANCHES, S. M.; VIEIRA, E. M.; PRADO, E. L.; BENETTI, F.; TAKAYANAGUI, A. M. M. Estudo da presença da toxina microcistina-LR em água utilizada em clínica de hemodiálise e validação de um método análítico. Eclética Química, v. 32, n. 4, p. 43-48, 2007. https://doi.org/10.1590/S0100-46702007000400006

SANTOS, R. C. L.; LIMA, Á. S.; CAVALCANTI, E. B.; MELO, C. M. DE; MARQUES, M. N. Aplicação de índices para avaliação da qualidade da água da Bacia Costeira do Sapucaia em Sergipe. Engenharia Sanitária e Ambiental, v. 23, n. 1, p. 33-46, 2018. https://dx.doi.org/10.1590/S1413-41522017159832

SILVA-STENICO, M. E.; CANTÚSIO NETO, R.; IVÂNIO, R.; ALVES, I. R.; MORAES, L. A. B.; SHISHIDOA, T. K. et al. Hepatotoxin Microcystin-LR Extraction Optimization. Journal of the Brazilian Chemical Society, v. 20, n. 3, p. 535-542, 2009. https://doi.org/10.1590/S0103-50532009000300019

SIVONEN, K.; JONES, G. Cyanobacterial toxins. In: BARTRAM, J. (ed.). Toxic Cyanobacteria in Water: A guide to their public health consequences monitoring and management. London: [s.n.], 1999. v. 22, p. 41-111.

SOTERO-MARTINS, A.; HANDAM, N. B.; MOURA, P. G.; AMARAL, L. S.; CALDAS, L. V. L.; CARVAJAL, E. Methods for Sanitary Inspection of Microbiological and Parasitary Quality of Water and Sand of Recreation Areas. American Journal of Engineering Research, v. 6, p. 56-2, 2017.

TE, S. H.; TAN, B. F.; BOO, C. Y.; THOMPSON, J. R.; GIN, K. Y. Genomics insights into production of 2-methylisoborneol and a putative cyanobactin by Planktothricoides sp. SR001. Standards in Genomic Sciences, v. 12, n. 1, p. 1-9, 2017. https://doi.org/10.1186/s40793-017-0247-1

TEIXEIRA, M. G. L. C.; COSTA, M. C. N.; PIRES DE CARVALHO, V. L.; PEREIRA, M. S.; HAGE, E. Epidemia de gastroenterite na area da barragem de Itaparica, Bahia. Bulletin of the Pan American Health Organization, v. 114, n. 6, p. 502-512, 1993.

UTSUMI, A. G.; GALO, M. L. B. T.; TACHIBANA, V. M. Mapeamento de cianobactérias por meio da fluorescência da ficocianina e de análise geoestatística. Revista Brasileira de Engenharia Agrícola e Ambiental, v. 19, n. 3, p. 273-279, 2015. https://doi.org/10.1590/1807-1929/agriambi.v19n3p273-279

WATSON, S. B.; MONIS, P.; BAKER, P.; GIGLIO, S. Biochemistry and genetics of taste- and odor-producing cyanobacteria. Harmful Algae, v. 54, p. 112-127, 2016. https://doi.org/10.1016/j.hal.2015.11.008 